\title{
Bewuste keus?
}

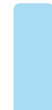

Het is nog maar kort geleden dat de uitbraak van het coronavirus COVID-19 de reguliere zorg in Nederland voor een belangrijk deel tot stilstand bracht. Inmiddels lijken de meeste huisartsenpraktijken de reguliere zorg en de ketenzorg voor chronische aandoeningen weer te hebben opgepakt. Ook zijn de bevolkingsonderzoeken (bvo's) gefaseerd hervat: medio mei het bvo darmkanker, een maand later borstkanker en sinds 1 juli ook het bvo baarmoederhalskanker. Maar komt men wel opdagen? Recente cijfers zijn er nog niet, maar in dit nummer concluderen Thomas Bongaerts et al. dat de landelijke opkomstcijfers de laatste jaren een dalende trend laten zien. En dat was vóórdat de coronacrisis losbarstte.

Volgens de WHO moet het deelnamepercentage van het screeningsprogramma boven de $70 \%$ zijn om effectief te zijn. Dat haalden we op het platteland maar net, laat staan in de grote steden. Vooral mensen geboren buiten Nederland en mensen met een lagere sociaal-economische status blijken minder gebruik te maken van de bvo's. Waarom? Niet deelnemen mag natuurlijk; de voordelen van een adequaat screeningsprogramma, zoals minder invasieve behandelingen door vroegdiagnostiek en een (lichte) reductie van kankergerelateerde mortaliteit, wegen niet voor iedereen op tegen de nadelen. Maar berust afzien van deelname in bovengenoemde groepen op een goed geïnformeerde keuze? Bij een deel van de wegblijvers lijkt de overtuiging te bestaan dat kanker nu eenmaal niet te genezen is, in welk stadium dan ook. Maar juist in een vroeg stadium is er nog veel mogelijk.

Zouden wij als huisarts niet een proactievere rol moeten pakken, juist bij deze groepen? Preventie valt ons immers als kerntaak ten deel. Sinds huisartsen een minder grote rol spelen bij de bvo's is de opkomst lager. Terwijl juist de huisarts dit gesprek goed kan voeren; we zijn gewend te vragen naar overtuigingen en doen altijd ons best informatie te geven die past bij het referentiekader van de patiënt, ondersteund door Thuisarts.nl. Goed dus om, met name bij bovengenoemde groepen, eens naar deelname te vragen en bij twijfels de ambivalenties te bespreken, zodat uw patiënt een goed afgewogen beslissing kan maken. Geen deelname is ook goed, maar het moet wel een bewuste keuze zijn.

Kim van Wijck, redactielid H\&W

\section{e? al-

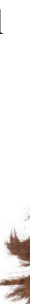

